\title{
JOINT COMMUNIQUE: THE THIRD ASEAN MINISTERS OF LAW MEETING
}

Manila, 13 September 1996

1. The Third Meeting of ASEAN Law Ministers was held in Manila on 13 September 1996.

5. The Ministers reaffirmed their commitment to the ASEAN Bangkok Declaration of 1967, the Declaration of ASEAN Concord of 1976, the ASEAN Ministerial Understanding on the Organizational Arrangement for Co-operation in the Legal Field, Bali, Indonesia, 1986, the Manila Declaration of 1987, the Singapore Declaration of 1992, and the Bangkok Summit Declaration of 1995, and agreed that the ASEAN Senior Law Officials Meeting (ASLOM) should continue to examine the role of law in the context of facilitating greater ASEAN co-operation.

6. The Ministers took note that the Attorneys-General of ASEAN held a Meeting in Jakarta on 24-25 July 1995 and that the Attorneys-General reached consensus in a document called the Jakarta Consensus.

7. The Ministers considered the recommendation of the ASEAN Senior Law Officials Meetings on 12-14 April 1993 in Kuala Lumpur and on 18-20 September 1995 in Bandar Seri Begawan that there would be co-operation in the exchange of legal materials and continuing legal education among ASEAN countries. The Ministers also agreed that each ASEAN Member Country shall designate its respective authority/agency as the focal point responsible for transmitting and receiving official requests for the exchange of legal materials. The cost of the legal materials, including administrative costs, shall be borne by the requesting country. A requested country may, however, waive such charge or costs. The requested country shall use its best endeavours to provide the requested legal materials.

8. The Ministers noted that the exchange of study visits by law officials of ASEAN Member Countries is to be strongly encouraged. Information on appropriate Continuing Legal Education Programmes available in ASEAN Member Countries shall be disseminated by and through the national focal points. Continuing Legal Education programmes undertaken by an ASEAN Member Country, where appropriate, are to be made available to other ASEAN Member Countries. Exchange of teachers and experts in the field of law among ASEAN Member Countries is also to be encouraged. The cost of such visits shall be borne by the requesting party. A requested country may, however, waive such charges or costs.

9. The Ministers endorsed the recommendation of the ASEAN Senior Law Officials Meeting on 11-12 September 1996 to request the ASEAN Secretariat to modify its Home

Asian Yearbook of International Law, Volume 7 (Ko Swan Sik et al., eds.

${ }^{\circ}$ Kluwer Law International; printed in the Netherlands), pp. 525-527 
Page to provide hypertext links to the legal information database of each Member Country as and when that Member Country sets up its database in order to further the objective of establishing an ASEAN Legal Information Network System.

\section{DECLARATION ON THE ESTABLISHMENT OF THE BANGLADESH - INDIA - SRI LANKA - THAILAND ECONOMIC COOPERATION (BIST-EC) \\ Bangkok, 6 June 1997}

The Minister ... [etc.], acting on behalf of their respective Governments;

Mindful of the existence of mutual interests and common concerns among their countries and complementarities of their economies and convinced of the potential for strengthening further the existing bonds of friendship and co-operation;

Desiring to establish a firm foundation for common action to promote sub-regional cooperation in the areas of trade, investment, technological exchange and other interrelated areas in a spirit of equality and partnership and thereby contribute towards peace, progress and prosperity in their common region;

Conscious that in an increasingly interdependent world, the cherished ideals of peace, freedom, and economic well-being are best attained by fostering greater understanding, good neighbourliness and meaningful co-operation among countries of the same sub-region already bound together by ties of history and culture;

Considering that countries share a primary responsibility for strengthening the economic and social stability of their sub-region and ensuring peaceful and progressive national development;

\section{DO HEREBY DECLARE:}

FIRST, the establishment of the Bangladesh-India-Sri Lanka-Thailand Economic Cooperation to be known as the BIST-EC.

SECOND, that the aims and purposes of the BIST-EC shall be:

1. To create an enabling environment for rapid economic development through identification and implementation of specific co-operation projects in the sectors of trade, investment and industry, technology, human resource development, tourism, agriculture, energy, and infrastructure and transportation. 